\title{
Assessment of Phagocytic Activity of Blood and Milk Neutrophils of Crossbred Cows during Peripartum Period
}

\author{
Krupa R. Joshi, M.M. Pathan*, S.P. Madhira, A.M. Pande and M.M. Islam \\ College of Veterinary Science \& Animal Husbandry, AAU, Anand, India \\ *Corresponding author
}

\section{A B S T R A C T}

\begin{tabular}{|c|}
\hline $\begin{array}{l}\text { Ke y w o r d s } \\
\text { Cow, Neutrophil, } \\
\text { Phagocytosis }\end{array}$ \\
\hline Article Info \\
\hline $\begin{array}{l}\text { Accepted: } \\
\text { 26 October } 2018 \\
\text { Available Online: } \\
\text { 10 November } 2018\end{array}$ \\
\hline
\end{tabular}

Six crossbred cows (Holstein Friesian $\times$ Kankrej) were investigated in their advance stage of gestation period for Phagocytic Activity (PA) of Blood and Milk. Blood was collected on days $-30,-15,-7$ and -3 before calving, on the day of calving and on days $3,7,15$ and 30 after calving while milk collected on the day of calving and 3, 7, 15, 30 day after calving. Highest Neutrophil (\%) was observed on $3^{\text {rd }}$ day before calving which was significantly $(\mathrm{p}<0.05)$ higher as compared to 30 day before calving. The PA of blood was observed significantly $(\mathrm{p}<0.05)$ lower at calving as compared to 15 day before calving. While the PA of milk neutropil was significantly $(\mathrm{p}<0.05)$ higher at calving as compared to 7, 15 and 30 days postpartum. Cortisol level was increased significantly on the day of calving as compared to pre-partum and postpartum days. This study indicated that the phagocytic activity of blood and milk neutropils get reduced during calving. Increasing level of glucocorticoids during calving is responsible for immunosuppression during peripartum period.

\section{Introduction}

The neutrophil is the most active phagocytic cell in the body. A large number of circulating neutrophils enter into the bovine Mammary gland during inflammation and provide resistance against most mammary pathogens (Straub et al., 1959; Newbould, 1970). Cows vary in their ability to resist mammary infection. As a result from microbial virulence (Newbould, 1967), poor phagocytic activity of neutrophils in milk (Newbould, 1973), physiological stressful situations such as parturition (Newbould, 1973). In this critical period the mammary gland undergoes marked biochemical, cellular and immunomodulatory changes to accommodate involution, to prepare for parturition, to withstand the stress of parturition, to transform colostrum into milk, and then for the attainment of peak milk production. These periods also coincide with impaired lymphocyte and neutrophil function. These immunological dysfunctions not only increase the risks of udder infection, mastitis, retained placenta and metritis but also lead to suppressed growth of mammary cells and subsequent milk production as energy and nutrients go preferentially to immune and homeostatic pathways (Kehrli et al., 1989). Although it is thought that the hormonal and metabolic factors may play a primary role in this physiological immune suppression, it can 
further be suppressed by nutritional insults (Grant and Albright, 1995). Therefore, it is important to understand the cellular defence mechanisms operative during peripatum period in the mammary gland in order to find new ways for maintaining the animal healthy and optimizing milk production (Drackley, 1999). Upon The polymorphonuclear neutrophils (PMNs) form the first line of cellular defence against invading pathogens, mainly by the process of phagocytosis (Paape and Wergin, 2003). During periparturient period immune system gets suppressed. At this time the most important factor causing immunosuppression are metabolic stress and stress of parturition resulting from hormonal and metabolic fluctuations, a negative energy balance, and shortage of proteins, minerals and vitamins which are required to meet the demands of the fetus as well as the onset of lactation. Decreased phagocytosis of neutrophils, decreased cytotoxic ability of lymphocytes, as well as depressed activity of their cytokines during parturition make it impossible for the normal, efficient maternal immune recognition and rejection of fetal membranes and finally results in their retention in cows (Mordak and Stewart, 2015). To achieve maximum production, work should be concentrated on ways of minimizing the negative influence on immune functions and/or ways of stimulating these functions, especially during the periods of immune suppression (Waller, 2000). Therefore, the present study was initiated to evaluate the phagocytic activity of neutrophils during the peripartum period and its relationship with plasma cortisol and prolactin.

\section{Materials and Methods}

Six crossbred cows (Holstein Fresian $x$ Kankrej) were selected in their advance stage of gestation with different parity from the Livestock Farm Complex (LFC), Department of Livestock Production Management at
College of Veterinary Science and A.H., Anand. The study was conducted on selected animals from 30 days before calving to 30 days after calving. The experimental animals were reared in semi-open housing system which is made up of concrete floor under asbestos roofed housing system constructed east west direction and well covered with trees.

From each experimental animal $9 \mathrm{ml}$ Blood was drawn in sterile heparinized vacutainer tube from jugular vein puncture, posing minimum disturbance to the animal during collection on days $-30,-15,-7$ and -3 before calving, on the day of calving and on days 3 , 7, 15 and 30 after calving. Blood samples were obtained from six cows as soon as possible after parturition and always within the first $24 \mathrm{hr}$. immediately after collection the samples were transported to the laboratory over ice for further processing. The blood sample was used to identify mature and immature neutrophil and neutrophil percentage. Plasma was separated by centrifugation at $3000 \mathrm{rpm}$ for 15 minutes and stored at $-20^{\circ} \mathrm{C}$ in deep freeze until analyzed for cortisol and prolactin. Isolation of PMN from remaining blood pellet was performed by hypotonic lysis of RBC and then centrifugation as described by Mehrzad et al., (2004). From each experimental animal 25ml milk sample was collected on the day of calving and 3, 7, 15, and 30 day after calving. Isolation of PMN from colostrum and milk was performed as per method described by Mehrzad et al., (2001). A semi-quantitative microscopic nitro blue tetrazolium (NBT) assay is used to determine in vitro procedure for measuring phagocytosis of blood neutrophils as described by Chai et al., (2005). Breifly 1 million viable neutrophils were culture with zymosan $(650 \mu \mathrm{g} / \mathrm{ml})$ and NBT $(250 \mu \mathrm{g} / \mathrm{ml})$ with RPMI medium in 96 well tissue culture plate. The plate was allowed to incubate at $37^{\circ} \mathrm{C}$ in a humidified $\mathrm{CO} 2$ incubator $(95 \%$ air and $5 \% \mathrm{CO} 2)$ for $2 \mathrm{~h}$. 
During the incubation phagocytic cells produce O2- anions. These O2- reduce the yellow colour water soluble NBT to water insoluble blue or purple colour formazan crystals. The optical density (OD) of the reduction product was determined at $540 \mathrm{~nm}$. Significance was tested by employing two ways ANOVA.

\section{Results and Discussion}

In the present study, we had found that the mean $( \pm$ SEM) of neutrophil $(\%)$ of crossbred cattle was increased significantly $(\mathrm{p}<0.05)$ from 30 day before calving to 3 day before calving which is the highest level of neutrophil percent observed during the study. A slight non-significant reduction in neutrophil percent was observed on the day of calving as compared to 3 day before calving. After parturition sudden significant $(\mathrm{p}<0.05)$ reduction in neutrophil percent was observed on $3^{\text {rd }}$ day after calving (Table 1). Mature and Immature neutrophils Percentage of crossbred cows during the peripartum period have been presented in Table 2. The number of mature neutrophils was significantly $(\mathrm{p}<0.05)$ reduced on the day of calving and number of immature neutrophils got increased during calving as compared to 15 days before and after calving. The mean $( \pm$ SEM) of PA of blood neutrophils was ranged from 30 days before calving $(0.25 \pm 0.01)$ to 3 days after calving $(0.50 \pm 0.08)$. The PA of blood neutrophil was increased significantly $(\mathrm{p}<0.05)$ on 15 day before calving from 30 day before calving which was suppressed significantly $(\mathrm{p}<0.05)$ on the day of calving. After calving a sudden significant $(\mathrm{p}<0.05)$ increase in PA was observed on $3^{\text {rd }}$ day of calving. Thereafter, again suppression in neutrophilic PA was observed. The mean $( \pm$ SEM) of PA of milk neutrophil ranged from the day of calving $(1.73 \pm 0.13)$ to 30 days after calving $(0.70 \pm 0.08)$ which was significant $(\mathrm{p}<0.05)$. Maximum activity of milk neutrophils observed on the day of calving, which was decreased significantly $(\mathrm{p}<0.05)$ on 3 day after calving. Significant $(p<0.05)$ reduction in the P.A. of milk neutrophils was observed at 30 days after calving (Table 1). During the peripartum period, blood plasma cortisol $(\mathrm{ng} / \mathrm{ml})$ levels ranged from the day of calving $(44.04 \pm 8.87)$ to 15 days after calving (22.99 \pm 2.63$)$. Continuous non-significant increase in level of cortisol was observed from 30 day before calving to on the day of calving which becomes highest on the day of calving. After calving non-significant reduction in cortisol was observed till 15 day of calving, which was again increased non-significantly on $30^{\text {th }}$ day of calving. Blood plasma prolactin (ng/ml) levels ranged from 30 days before calving $(188.97 \pm 24.53)$ to on the day of calving (333.28 \pm 4.27$)$ which was significant $(p<0.05)$. Continuous increase in level of prolactin was observed from 30 day before calving to on the day of calving which became highest on the day of calving. After calving non-significant reduction observed in prolactin till 30 day after calving (Table 1).

We found the highest value of neutrophil on the day of calving as compared to pregnancy which was similar with Pomsel (1980) and Kim et al., (2005). Neutrophil per cent had a highly significant $(\mathrm{p}<0.01)$ positive correlation with level of cortisol and level of prolactin. So that the increasing level of cortisol around calving might be acting as stimulating agent for the increased neutrophil per cent around calving. Paape et al., (1973) reported that the rapid increase of circulating neutrophils was attributed mainly to an influx of neutrophils from the hematopoietic system and not from a marginal pool of mature leukocytes. A higher level of cortisol around calving is the reason behind an increase in immature neutrophils. Mature neutrophils are more sensitive to cortisol as compared to immature neutrophils and have more number of glucocorticoid receptors as compared to immature 
neutrophils. Migration of mature neutrophils from the bone marrow reduces due to reduction in number of adhesion receptors (Lselectin and CD18). Immature neutrophils are less affected due to lower effect of cortisol in response to lower number of glucocorticoid receptors. So, they marginate more from hematopoietic reserve as compared to mature neutrophils (Burton et al., 2005).

Blood PMN functions required for killing the pathogens and initiation of phagocytosis such as chemotaxis and diapedesis (Shuster et al., 1996) are also compromised during early lactation. This suppression was found associated with the sudden changes in concentrations of ketone bodies (Suriyasathaporn et al., 1999), glucocorticosteroids (Guidry et al., 1976) and pregnancy and lactation-associated molecules (Hoeben et al., 2000). These changes probably contribute for lowering the PA of neutrophils during period immediately after calving in cows. Upon estimation of plasma cortisol it was revealed that the highest cortisol concentration was at calving. Diminished neutrophil functions and compromised host resistance mechanisms during peripartum period in dairy cows have also been observed by Meglia et al., (2001) and Dang et al., (2012). Poor activity of neutrophils at calving may be due to more number of immature neutrophils coming in circulation which have no proper machinery to fight or phagocytose against infection. Reduction in phagocytic activity was significant $(\mathrm{p}<0.05)$ on the day of calving as compared to 15 day before calving. This suppression in the PA might be due to a sharp increase in the cortisol levels at calving. In the present study, a significant $(\mathrm{p}<0.05)$ negative correlation was observed between PA of blood neutrophils and plasma cortisol levels. There was increased neutrophil numbers during parturition but phagocytic activity remained lower in the present study. Parturition reflex causes higher plasma cortisol level that leads to hyper stimulation of red bone marrow for the faster release of neutrophils. As a result of this, there was release of more number of immature neutrophils and a less number of matured neutrophils. That is why, the phagocytic activity of neutrophils decreased as observed in the present study. According to Meglia et al., (2001), neutrophils and their important functions, like migration and phagocytosis, are impaired when the animal is under stress of calving. During prepartum period (15 day before calving) animals are in dry stage so, there is no stress of milk production but at parturition, animals have to face stress of calving, synthesize colostrum (up to 3 days) and milk. Dang at al., (2014) reported that Changes occurred in the PA of blood neutrophils in primiparous and multiparous crossbred cows during different days of lactation cycle. Phagocytic activity in both the group of cows started decreasing from 15 days prepartum and maximum depression was observed at calving. This indicated that immunosuppression of the neutrophilic activity starts from 2 weeks before parturition and remained low until day of lactation.

Phagocytic activity was maximum in Neutrophils obtained from colostrums. Sugisawa et al., (2001) found that as the immunoglobulins were very high in colostrums as compared to milk, therefore, it increased the PA of colostrum neutrophils by up to $25 \%$ and was dose dependent. Further, PA was higher in the colostrums of multiparous animals because they produce more immunoglobulins in their colostrums and PA decreased between day 30 and 60 i.e. when the animal attains peak yield, which might be due to hormonal and metabolic changes such as glucocorticoids, ketone bodies and pregnancy associated glycoprotein (Dang et al., 2009). 
Table.1 Mean $( \pm$ SE) values of Neutrophil, phagocytic activity (PA) of blood and Milk neutrophil, plasma Cortisol and Prolactin of crossbred cows $(n=6)$ during peripartum period

\begin{tabular}{|c|c|c|c|c|c|}
\hline Days & $\begin{array}{c}\text { Neutrophil } \\
(\%)\end{array}$ & $\begin{array}{c}\text { P.A. of } \\
\text { Blood } \\
\text { Neutrophil }\end{array}$ & $\begin{array}{c}\text { P.A. of } \\
\text { Milk } \\
\text { Neutrophil }\end{array}$ & $\begin{array}{l}\text { Cortisol } \\
(\mathrm{ng} / \mathrm{ml})\end{array}$ & $\begin{array}{l}\text { Prolactin } \\
(\mathrm{ng} / \mathrm{ml})\end{array}$ \\
\hline-30 & $38.34^{\mathrm{b}} \pm 2.42$ & $0.25^{c} \pm 0.01$ & - & $27.69^{b} \pm 5.22$ & $188.97^{c} \pm 24.53$ \\
\hline-15 & $41.55^{\mathrm{b}} \pm 0.77$ & $0.51^{\mathrm{a}} \pm 0.15$ & - & $25.04^{\mathrm{b}} \pm 6.20$ & $268.44^{\mathrm{b}} \pm 27.69$ \\
\hline-7 & $42.83^{b} \pm 0.83$ & $0.41^{\mathrm{abc}} \pm 0.08$ & - & $26.67^{b} \pm 3.48$ & $309.00^{\mathrm{ab}} \pm 29.65$ \\
\hline-3 & $46.79^{a} \pm 2.43$ & $0.28^{b c} \pm 0.07$ & - & $28.60^{\mathrm{ab}} \pm 5.15$ & $306.75^{\mathrm{ab}} \pm 14.75$ \\
\hline 0 & $45.69^{a} \pm 2.37$ & $0.27^{b c} \pm 0.02$ & $1.73^{\mathrm{a}} \pm 0.13$ & $44.04^{\mathrm{a}} \pm 8.87$ & $333.28^{\mathrm{a}} \pm 4.27$ \\
\hline 3 & $40.71^{b} \pm 1.88$ & $0.50^{\mathrm{a}} \pm 0.08$ & $1.31^{\mathrm{ab}} \pm 0.14$ & $38.61^{\mathrm{ab}} \pm 8.73$ & $287.43^{\mathrm{ab}} \pm 32.05$ \\
\hline 7 & $42.65^{b} \pm 1.75$ & $0.35^{\mathrm{abc}} \pm 0.06$ & $0.79^{c} \pm 0.15$ & $32.28^{\mathrm{ab}} \pm 7.99$ & $298.42^{\mathrm{ab}} \pm 13.66$ \\
\hline 15 & $41.86^{\mathrm{b}} \pm 0.90$ & $0.26^{c} \pm 0.03$ & $0.99^{b c} \pm 0.11$ & $22.99^{b} \pm 2.63$ & $312.25^{\mathrm{ab}} \pm 20.11$ \\
\hline 30 & $36.51^{\mathrm{b}} \pm 0.34$ & $0.36^{\mathrm{abc}} \pm 0.04$ & $0.70^{c} \pm 0.08$ & $35.66^{\mathrm{ab}} \pm 6.18$ & $305.35^{\mathrm{ab}} \pm 20.66$ \\
\hline $\begin{array}{l}\text { Overall } \\
\text { Mean }\end{array}$ & $\begin{array}{c}41.89 \pm \\
1.52\end{array}$ & $0.36 \pm 0.07$ & $1.10 \pm 0.13$ & $31.29 \pm 5.84$ & $289.99 \pm 17.13$ \\
\hline CV\% & 10.24 & 49.05 & 28.04 & 45.72 & 14.47 \\
\hline $\mathrm{CD}_{0.05}$ & 3.94 & - & 0.37 & - & 48.97 \\
\hline
\end{tabular}

Table.2 Mean $( \pm$ SE) values of mature and immature neutrophil of crossbred cows $(n=6)$ during peripartum period

\begin{tabular}{|c|c|c|c|c|}
\hline & -15 & 0 & 15 & Overall Mean \\
\hline $\begin{array}{c}\text { Mature Neutrophil } \\
(\%)\end{array}$ & $98.07^{\mathrm{a}} \pm 0.15$ & $94.67^{\mathrm{b}} \pm 0.26$ & $99.13^{\mathrm{a}} \pm 0.18$ & $\mathbf{9 7 . 2 9} \pm \mathbf{0 . 2 0}$ \\
\hline $\begin{array}{c}\text { Immature } \\
\text { Neutrophil (\%) }\end{array}$ & $2.93^{\mathrm{b}} \pm 0.07$ & $5.33^{\mathrm{a}} \pm 0.18$ & $0.87^{\mathrm{c}} \pm 0.09$ & $\mathbf{3 . 0 4} \pm \mathbf{0 . 1 1}$ \\
\hline
\end{tabular}

*Values having different superscripts differed significantly $(\mathrm{p}<0.05)$ within Row 
Mohapatra, (2012) also reported that phagocytic activity of milk neutrophil was higher on the day of calving and significantly decrease on 15 day postpartum. The present result also collaborated with this study. Phagocytic activity was generally lower in milk than in blood neutrophils (Vishnoi et al., 2007). The reason for this is that as milk neutrophils have reduced glycogen stores compared to that of blood, this might limit the availability of energy. Milk neutrophils also have reduced abilities to produce Reactive Oxygen Species (ROS) as compared to that of blood (Dosogne et al., 2001). The decreased bactericidal activity of milk PMN in comparison with blood PMN could also be explained by a lower super oxide production measured by chemiluminescence's (Dulin et al., 1988) and a lower $\mathrm{H}_{2} \mathrm{O}_{2}$ production measured by flow cytometry (Salgar et al., 1991). An increased concentration of neutrophils in the first day colostrums provides immunity to the mammary gland. Migration of polymorphonuclear neutrophil leukocytes (PMN) into the mammary gland provides the first line of defense against invading mastitis pathogens (Craven and Williams, 1985; Tizard, 2000). Neutrophils travel from blood to the mammary gland in response to a variety of inflammatory mediators, such as cytokines, complement and prostaglandins (Zecconi and Smith, 2000; Janeway et al., 2001).

Cortisol is the most important glucocorticoid and is produced by the adrenal gland. It is released in response to stress and a low level of blood glucocorticoids. Its primary functions are to suppress the immune system and increase blood sugar through gluconeogenesis. The cows during peripartum period are under various types of stressful conditions during stress of providing nutrition to its growing calf, stress of labour, to synthesize colostrum and then milk. A social stress of being isolated is also there. Overall effects of stress cause increased cortisol level, produced neutrophilia with decreased functional capacity of neutrophils which leads to immunosupression and ultimately the cows become more prone to mastitis and other infections (Kehrli et al., 1991). High levels of cortisol at calving have also been reported (Goff and Horst, 1997) to act as powerful immunosuppressive agent. The result of present study also collaborated with the findings of Prakash and Madan (1985) in buffaloes, Goff and Horst, (1997) in cows and Khan and Ludri (2002) in crossbred goats. The value of plasma cortisol concentration observed in our study was similar to that reported by Pal (1996) in crossbred KF cows. Mukherjee et al., (2015) observed increase in prolactin in peripheral circulation during the day of parturition. Peak value of prolactin attained at parturition and returned to basal levels within 2 weeks. Similar results were observed during present study. Kodagali et al., (1980) reported that the prolactin concentration varied with each stage of lactation; being high in early, middle in mid lactation, and low in late lactation in Gir cows. The present study also accordance with Akasha et al., (1987), where serum prolactin concentration declined as lactation progressed.

In conclusion, blood phagocytic activity (PA) suppressed on the day of calving due to immunosuppression even after neutrophil percent observed higher. While milk PA observed higher on the day of calving because of their immunoglobulin and hormonal changes. Cortisol and prolactin level highest observed on the day of calving but the effect of prolactin on blood neutrophilic activity was non-significant.

\section{References}

Akasha, M. A, Anderson, R. R., Ellersieck, M., Nixon, D. A. (1987). Concentrations of thyroid hormone and prolactin in dairy 
cattle serum and milk at three stages of lactation. Journal of Dairy Science, 70: 271-276.

Burton, J. L., Madsen, Sally A., Chang, LingChu; Weber, Patty S.D., Buckham, Kelly R., Dorp, Renate Van; Hickey, Marry Clare and Earley Bernadette, (2005). Gene expression signatures in neutrophils exposed to glucocorticoids: A new paradigm to help explain "neutrophil dysfunction" in parturient dairy cows. Veterinary Immunology Immunopathoogy, 105(3-4): 197-219.

Chai, E. Mi., Kim, Y., Kim, A., Hwang, J., (2005). Immunomodulating activity of arabinogalactin and fucoidan in vitro. Journal of Medicinal Food, 8(4): 446455.

Craven, N. and Williams, M.R. (1985). Defenses of the bovine mammary gland against infection and prospects for their enhancements. Veterinary Immunology and Immunopathology, 2:71.

Dang, A. K., Mukherjee, J., Chaudhury, M., Prasad, S., Mohanty, A. K., Kapila, S., and Kapila, R. (2013). In vitro phagocytic activity of blood and milk neutrophils against Saccharomyces cerevisiae in primiparous and multiparous Karan Fries crossbred cows throughout the dry period and lactation cycle. Indian Journal of Animal Science, 843, 262-266.

Dang, A. K., Prasad, S., De, K., Pal, S., Mukherjee, J., Sandeep, I. V. R., Mutoni, G., Pathan, M. M., Jamwal, M., Kapila, S., Kapila, R., Kaur, H., Dixit, S., Mohanty, A. K. and Prakash, B. S. (2012). Effect of supplementation of vitamin $\mathrm{E}$, copper and zinc on the in vitro phagocytic activity and lymphocyte proliferation index of peripartum Sahiwal (Bos indicus) cows. Journal of Animal Physiology and Animal Nutrition, 97(2): 315-321.

Dang, A.K., S. Kapila, M. Purohit and C. Singh. (2009). Changes in colostrums of Murrah buffaloes after milking. Trop. Anim. Heath Pro., 41: 1213-1217.
Dosogne, H., Vangroenweghe, F. Barrio, B., Rainard, P. and Burvenich, C. (2001). Decreased bactericidal activity of bovine blood and milk neutrophils against staphylococcus aureus in dairy cows shortly after parturition. Journal of Dairy Research, 68:539-549.

Drackley, J. K. (1999). Biology of dairy cows during the transition period: the final frontier? Journal of Dairy Science, 82: 2259-2273.

Dulin, A.M., Paape, M.J., Nickerson, S.C., (1988). Comparison of phagocytosis and chemiluminescence by blood and mammary gland neutrophils from multiparous and nulliparous cows. American Journal of Veterinary Research, 49: 172-177.

Goff, J.P. and R.L. Horst. (1997). Physiological changes at parturition and their relationship to metabolic disorders. Journal of Dairy Science, 80:1260-1263.

Grant, R.J. and Albright, J.L. (1995). Feeding behavior and management factors during the transition period in dairy cattle. Journal of Animal Science, 73: 2791-2803.

Guidry, A. J., Paape, M. J., and Pearson, R. E. (1976). Effects of parturition and lactation on blood and milk cell concentrations, corticosteroids, and neutrophil phagocytosis in the cow. American journal of veterinary research, 37(10), 1195-1200.

Hoeben, D., Monfardini, E., Opsomer, G., Burvenich, C., Dosogne, H., de Kruif, A., and Beckers, J. F. (2000). Chemiluminescence of bovine polymorphonuclear leucocytes during the periparturient period and relation with metabolic markers and bovine pregnancy-associated

glycoprotein. Journal of Dairy Research, 67(2), 249-259.

Janeway, C.A., Travers, P., Walport, M. and Shlomchik, M. (2001). Basic concepts in immunology. In: Immunobiology: The immune system in health and disease. 
Kehrli, M. E., Weigel, K. A., Freeman, A. E., Thurston, J. R., and Kelley, D. H. (1991). Bovine sire effects on daughters' in vitro blood neutrophil functions, lymphocyte blastogenesis, serum complement and conglutinin levels. Veterinary Immunology and Immunopathology, 27: 303-319.

Kehrli, M. J., Nonnecke, B. J., Roth, J. A., (1989). Alternations in bovine neutrophil function during the periparturient period. American Journal of Veterinary Research, 50(2): 207 214.

Khan, J. R. and Ludri, R. S. (2002). Hormone profile of crossbred goats during the periparturient period. Tropical Animal Health and Production, 34: 151-62.

Kim, I. H., Na, K. J., and Yang, M. P. (2005). Immune responses during the peripartum period in dairy cows with postpartum endometritis. Journal of Reproduction and Development, 51(6), 757-764.

Kodagali, S.B., Deshpande, B.R., Sane, C.R., Sheth, A.R., Shah, G.V. and Gadgil, B.A. (1980). Serum prolactin levels of postpartum Gir cows. Indian Journal of Dairy Science. 32:185-187.

Meglia, G.E. Johannisson, A. Agenäs.S., Holtenius, K. and Waller, K.P. (2001). Effects of feeding intensity during the dry period on leukocyte and lymphocyte sub-populations, neutrophil function and health in periparturient dairy cows. Vet. J. 169(3): 376-84.

Mehrzad, J., Dosogne, H., Meyer, E. and Burvenich, C. (2001). Local and systemic effects of endotoxin mastitis on the chemiluminescence of milk and blood neutrophils in dairy cows. The Journal of Veterinary Research. 32:131-144.

Mehrzad, J., Duchateau, L., and Burvenich, C. (2004). Viability of milk neutrophils and severity of bovine coliform mastitis. Journal of Dairy Science, 87(12), 41504162.
Mohapatra A. (2012). Morphology, Viability and Activity of Blood and Milk Neutrophils in Lactating Buffaloes. (Doctoral dissertation of National Dairy Research Institute, Karnal.

Mordak, R., and Stewart, P. A. (2015). Periparturient stress and immune suppression as a potential cause of retained placenta in highly productive dairy cows: examples of prevention. Acta Veterinaria Scandinavica, 57(1), 84.

Mukherjee, J., Mallick, S., Chaudhury, M., Prakash, B. S., and Dang, A. K. (2015). Infradian rhythmicity in milk leukocyte activity together with plasma cortisol and prolactin levels throughout the lactation period in high-yielding crossbred cows. Biological rhythm research, 46(6), 909-917.

Newbould, F. H. S. (1970). Enhancement of phagocytosis in bovine milk leukocytes in vitro. Can. J. comp. Med. 34: 261264.

Newbould, F. H. S. (1967). Some effects of the source of bovine milk leukocytes and strain of Staphylococcus aureus on their interaction in vitro. Can. J. comp. Med. 31: 303-308.

Newbould, F. H. S. (1973). The effect of added serum and glucose, and some inherent factors, on phagocytosis in vitro by milk leukocytes from several cows. Can. J. comp. Med. 37: 189-194.

Paape, M. J., Schultze, W. D. and Miller, R. H. (1973). Leukocytic response to adrenocorticotropic hormone as influenced by the infectious history of the mammary gland. Journal of Dairy Science, 56: 733-737.

Paape, M. J. and Wergin, W.P. (2003). The leukocyte as a defense mechanism. Journal of the American Veterinary Medical Association, 170: 1214-1223.

Pal, Y. (1996). Circulatory levels of some hormones and metabolites during initiation and early lactation in crossbred cows and buffaloes. [PhD 
thesis]. Karnal: National Dairy Research Institute.

Pomsel, T. (1980). Hamatologische Normalwerte beim Riind in Abhangigkeit von Alter und Trachtigkeit. Berlin (Doctoral dissertation, Dissertation).

Prakash, B. S., and Madan, M. L. (1985). Concentrations of plasma hormones in relation to placental retention in Karan Swiss cows during and after induction of parturition with dexamethasone and stilboestrol dipropionate. Animal Science, 40(1), 1-9.

Salgar, S.K., Paape, M.J., Alston-Mills, B. and Miller, R.H. (1991). Cytometric Study of oxidative burst activity in bovine neutrophils. American Journal of Veterinary Research, 52:1201-1207.

Shuster, D. E., Lee, E. K., Kehrli, M. E. (1996). Bacterial growth, inflammatory cytokine production and neutrophil recruitment during coliform mastitis in cows within ten days after calving. American Journal of Veterinary Research, 57, 1569-1575.

Straub, O. C., O. W. Schalm, J. P. Hughes and G. H. Theilen. (1959) Bovine hematology TI. Effect of parturition and retention of fetal membranes on blood morphology. J. Am. vet. Med. Ass. 135: 618-622.

Sugisawa, H., Itou, T., Saito, M., Moritomo, T., Miura, Y. and Sakai, T. (2003). A low- molecular-weight fraction of bovine colostrum and milk enhances the oxidative burst activity of polymorphonuclear leukocytes. Veterinary Research Communication. 27:453-461.

Suriyasathaporn, W., Daemen, J. M., Noordhuizen-Stassen, E. N., Nielen, S., Dieleman, J. and Schukken, Y. H. (1999). B-hydroxybutyrate levels in peripheral blood and ketone bodies supplemented in culture media affect the in vitro chemotaxis of bovine leukocytes. Veterinary Immunology and Immunopathology 68: 177-86.

Tizard, I.R. (2000). Veterinary Immunology, 6th edition. W.B. Saunders Company, Philadelphia.

Vishnoi, P.C., Dang, A.K. and Kapila, S. (2007). In vitro phagocytic activity of neutrophils in blood, normal and infected milk of Murrah buffaloes. Buffalo Journal, 1:51-59.

Waller, K.P. (2000). Mammary gland immunology around parturition. Influence of stress, nutrition and genetics. Advances in Experimental Medicine and Biology, 48: 231-45.

Zecconi, A. and Smith, K. L. (2000). Mammary gland immunological components. In: International symposium on ruminant mammary gland immunity, International Dairy Federation, p.7-47.

\section{How to cite this article:}

Krupa R. Joshi, M.M. Pathan, S.P. Madhira, A.M. Pande and Islam, M.M. 2018. Assessment of Phagocytic Activity of Blood and Milk Neutrophils of Crossbred Cows during Peripartum Period. Int.J.Curr.Microbiol.App.Sci. 7(11): 3173-3181. doi: https://doi.org/10.20546/ijcmas.2018.711.365 